\title{
Training New Housing Entrepreneurs - A Malaysian Scenario
}

\author{
Mastura Jaafar, Syed Putra Syed Abu Bakar and \\ Wan Mohd Dzulkifli Wan Daud \\ Additional information is available at the end of the chapter \\ http://dx.doi.org/10.5772/58943
}

\section{Introduction}

\subsection{Housing development industry in Malaysia}

Housing is a basic human need that not only serves as a shelter, but also is a simultaneous source of luxury, investment, privacy, and comfort. In Malaysia, the housing sector is an indispensable indicator of economic empowerment because the meeting of housing needs for all people has long been an objective of national policy [1]. Housing is an important wealth constituent [2] that affects the welfare of all people either directly or indirectly [3] in the form of improved living environments. Moreover, the housing sector significantly affects the macroeconomy of Malaysia: in 1996, it contributed 4.5\% to the growth domestic product [4] and acted as a tool to 'pump prime' the economy following the Asian financial crisis from 1997 to 1998 [5].

Residences cannot be developed without housing developers [6]. According to Jaafar et al. [7], housing development is the provision of money to build residential estates under stipulated rules and regulations. Such development is a localized [8], unique, and high-risk industry given the imposition of regulations [7] that may inevitably affect the construction process. To start a housing development business, entrepreneurs should have a large cash capital of no less than RM 250,000 [9]. Therefore, such entrepreneurs must have a disposition for risk-taking. By contrast, Abdul-Aziz et al. [10] claim that housing developers are risk-averse and that they maximize profits without thinking overly about risks and challenges.

Jaafar et al. $[7,11]$ also define housing developers as the chief coordinators that construct residential dwellings for sale and profit. Housing developers convert on-paper ideas into housing products [12] as project initiators [6]. In Malaysia, housing developers must obtain a 
license from the Ministry of Housing and Local Government (MHLG) [13], and they are encouraged to register as members of the Real Estate and Housing Developers' Association Malaysia (REHDA) [14]. Khalid [15] has also defined the term 'private housing developers' as businesses/entrepreneurs who provide housing units for sale. These businesses/entrepreneurs hold both an MHLG license and a membership in REHDA. However, Jaafar and Wan-Daud [16] contend that those who have developed four or fewer housing units, or who have sold four or fewer lots of land, cannot be considered housing developers because they deviate from the Housing Development Act (Control and Licensing) established in 1966. Therefore, they are known as micro-housing developers in the current study. With regard to size (in terms of number of houses), small-scale developers have developed 5-49 houses; medium-scale developers have built 50 -200 housing units; and large-scale developers have erected more than 200 units for each project.

\begin{tabular}{lccc}
\hline Programme: & \multicolumn{2}{c}{ Ninth Malaysia Plan (2006-2010) } \\
\hline Public sector & Low cost: & Medium cost: & High cost: \\
\hline Low-cost housing & $\mathbf{8 5 , 0 0 0}$ & $\mathbf{2 7 , 1 0 0}$ & $\mathbf{2 8 , 7 0 0}$ \\
\hline Housing by commercial agencies & 67,000 & - & - \\
\hline Housing by land schemes & 13,500 & 8,200 & 4,700 \\
\hline Institutional accommodation quarters for staff & 4,500 & - & - \\
\hline Private sector & - & 18,900 & $\mathbf{2 4 , 0 0 0}$ \\
\hline Private developers & $\mathbf{8 0 , 4 0 0}$ & $\mathbf{1 8 3 , 6 0 0}$ & $\mathbf{1 9 9 , 0 9 5}$ \\
\hline Cooperative societies & 77,700 & 178,000 & 194,495 \\
\hline Total & 2,700 & 5,600 & 4,600 \\
\hline
\end{tabular}

Source: Malaysia (2006)

Table 1. Housing targets of the public and private sectors in Malaysia (units)

Both the public and private sectors provide housing in Malaysia. Since the declaration of the country's independence, the public sector has assumed the role of providing housing for people. The housing projects constructed by this sector are normally funded by the government, and these funds are allocated from the national budget [17]. Nonetheless, Jaafar et al. [11] note that private housing developers are also key suppliers of new housing in Malaysia. Thus, they have considerable influence on the industry. Their housing schemes are normally self-financed, deposited through would-be buyers, or obtained from the financial market [17]. In fact, the private sector has provided houses more effectively than the public sector under the National Housing Policy [18] given the economic conditions that allow the private sector to secure high returns in the industry [14].

The housing development sector in Malaysia has transformed significantly since the country gained its independence in 1957 [10]. In the Second Malaysia Plan (from 1971 to 1975), the private sector increased its influence when the government sought the cooperation of private developers in the provision of low-cost houses. As per this plan, at least $30 \%$ of the houses in 
each private housing project must be low cost. The private sector has exceeded this set target by providing a surplus of $41 \%, 29.4 \%$, and $116 \%$ of houses over the past three consecutive Malaysia Plan periods (1991-1995, 1996-2000, and 2000-2005, respectively). Table 1 shows the actual housing provision target for the period of 2006-2010 in Malaysia. In the Ninth Malaysia Plan, the private sector is required to construct 80,400 low-cost housing units, 183,600 mediumcost units, and 199,095 high-cost units. Unfortunately, the government has not documented the statistics for the targets in the Tenth Malaysia Plan (2011-2015) and for the housing erected by the public and private sectors.

\subsection{Housing demand and supply}

The universal demand for housing increases over time primarily as a result of demographic trends and rising income [19]. Since the rapid urbanization that began in 1960, a significant budget has been allocated for housing provision in every five-year Malaysian development plan, especially for the urban areas [20]. The main factors that spur the strong housing demand are population growth and age profile, urbanization and migration, and household income. However, gender, occupation, education, and transportation costs also influence high public demand. Moreover, housing demand can also be associated with the preferred housing choices of local homebuyers, which mainly vary in terms of housing category, zone, project size, and project period [21].

\begin{tabular}{|c|c|c|c|c|}
\hline Year & Numbers (Million) & $\begin{array}{c}\text { Average annual growth } \\
\text { rate }(\%)\end{array}$ & $\begin{array}{c}\text { Population density (persons } \\
\text { per sq. km.) }\end{array}$ & Urbanization (\%) \\
\hline 1970 & 10.4 & 3.9 & 31.0 & 26.9 \\
\hline 1980 & 13.7 & 2.3 & 42.0 & 34.2 \\
\hline 1991 & 18.4 & 2.6 & 56.0 & 50.6 \\
\hline 2000 & 23.3 & 2.6 & 71.0 & 61.8 \\
\hline 2010 & 28.3 & 1.9 & 85.0 & 71.0 \\
\hline 2020 & 31.6 & 1.1 & 95.0 & 83.0 \\
\hline
\end{tabular}

Table 2. Population growth, density, and urbanization of Malaysia (1970-2020)

Table 2 indicates population growth, density, and urbanization in Malaysia from 1970 to 2020. The Malaysian population has increased from 10.4 million to 28.3 million at an average rate of $2.5 \%$ over the past four decades (1970-2010), which denotes an increase of almost three times. The population size is expected to reach 31.6 million in 2020 at an average growth rate of $1.1 \%$, as per the projection of statisticians. The population density in Malaysia increased from 31 people per square kilometre in 1970 to 42 in 1980, then to 56 in 1991 and to 71 in 2000. Likewise, the level of urbanization in this country also increases. The percentage of the population residing in urban areas increased from $26.9 \%$ in 1970 to $34.2 \%$ in 1980 and $50.6 \%$ in 1990 . By 
2000, more than two-thirds of the population (61.8\%) was located in the urban areas of Malaysia [22]. Studies by national scholars [19-20, 23] substantiated this scenario by reporting the decline of the rural population to $36 \%$ and the steady growth of the urban populace in 2005 . These circumstances aggravate competition among private housing developers to fulfil housing needs and enhance housing development in the country.

The Malaysian government addresses the substantial increase in housing demand through the MHLG. This department has actively set the direction for national development plans with respect to housing [4]. At present, it provides input and directs issues related to housing deliberation, needs, and target numbers. Furthermore, it collaborates with other parties to implement related programmes, strategies, and plans. Aside from the aforementioned responsibilities, the critical role of MHLG is to monitor the effectiveness of housing procedures in Malaysia to protect the benefits of all stakeholders.

\subsection{Housing policies in Malaysia}

The Malaysian government has formulated a set of policies to strengthen the involvement of the private sector in housing production and delivery [14]. Its housing policy is definitive, and is articulated adequately in all of the five-year Malaysia Plans [24]. Furthermore, this policy primarily aims to ensure that all Malaysians have access to adequate and decent shelter to eliminate slum dwellings and squatter living areas. The MHLG plans the regulation of residential developments, issues licenses and permits for advertisement and sale to housing developers, and ensures that all parties involved abide by all of the legislations and regulations through proper enforcement and by providing necessary financial assistance [5]. Specifically, the ministry is tasked with enforcing housing-related laws and regulations to safeguard the interests of homebuyers [25]. The MHLG also considers applications for development and for the licensing of housing developers in Peninsular Malaysia [9].

The Malaysian housing industry is highly controlled by several laws, policies, and guidelines, which include the National Land Code (NLC) 1965, Government Act 1976 (Act 171), Uniform Building By-Law 1984 (UBBL), Environmental Quality Act 1984, Local Government Act 1976, Street, Drainage and Building Act 1974 (Act 133), Town and Country Planning Act 1976 (Act 172), Town Planning Act 1995, Housing Developers (Control and Licensing) Act 1966, Strata Titles Act 1985, Fire Services Act 1988, and Sewerage Services Act 1993, as outlined by Abdullah et al. [26]. In addition to these laws, housing developers who design the layout of proposed housing projects should consider the requirements imposed by the local authority and the demand factor of the project [15] to ensure business survival.

\subsection{Housing development process}

To implement a housing development project, homebuilders should perform the following: acquire land, alter land use to suit the intended development purpose, integrate resources required for the projects, interpret the demand and supply of the market, provide housing units, and finally sell the completed houses. Furthermore, actual housing projects must also incorporate the provisions of various prescribed facilities and amenities as well as safeguard 
the environment [27]. Jaafar et al. [28] posit that the most critical supporting factors of housing development are finance, land, building materials, and consultancy services. Appointed consultants, who generally include architects and engineers, must follow all of the regulations imposed by the government; these regulations include obtaining permission approval, following the guidelines for construction activities, and adhering to the conditions imposed upon completion of a project, such as procedures for procuring a Certificate of Completion and Compliance (CCC).

Figure 1 presents the processes and procedures involved in project development. Jaafar and Wan-Daud [16] state that the practices are quite similar for both large and small projects. However, micro-developers without a development license must provide certain infrastructure facilities, such as elevated water tanks, electricity sub-stations, and other public amenities.

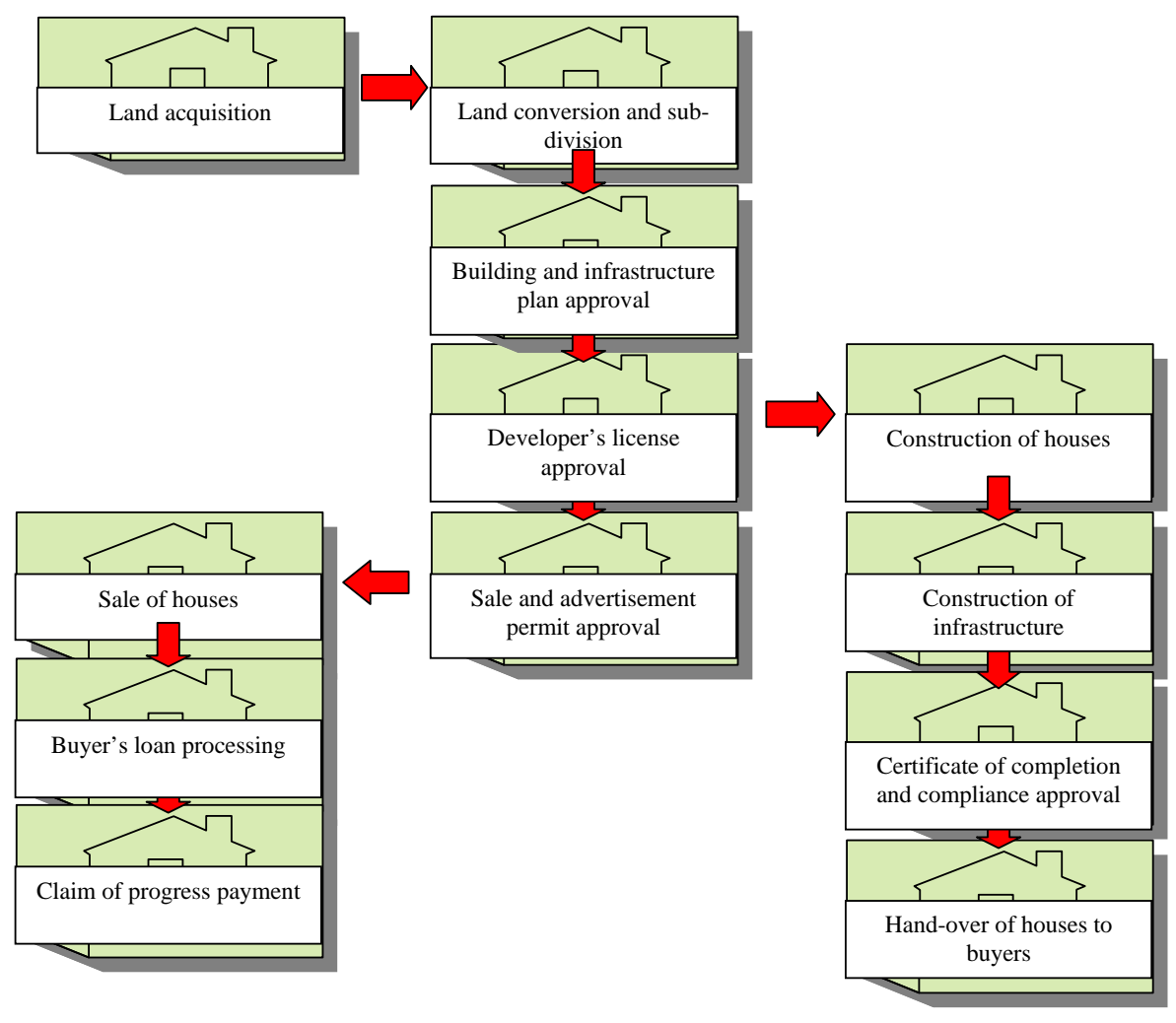

Figure 1. Developing New Micro-Housing Developers through Training

Hynes and Richardson [29] define training as a knowledgeable initiative to educate specific skills for the enhancement of individuals and organizations. Training nascent entrepreneurs is important because it encourages a tendency to start a business [30] and boosts the likelihood 
of entrepreneurial intention [31]. According to de Mel et al. [32], increased profits and improved management practices can be formed with efficient training, which is believed to reduce the rate of business failures [33]. An ideal scenario could be achieved if entrepreneurs can quickly adapt to the industry and the environment. As a part of entrepreneurial activities, the success of housing entrepreneurs also depends on flexibility and uncertainties.

The Malaysian housing sector is commonly referred to as 'a rich businessman's game' that is monopolized by large companies, including S P Setia Berhad, Sunway Berhad, Mah Sing Group Berhad, Paramount Corporation Berhad, UM Land, and a few government-related agencies. The lucrative returns of the housing sector have attracted companies from different sectors to join the industry. Sime Darby Plantation, YTL Communications, and Naza Motor Trading Sdn Bhd are only a few examples of mega players in other industries that have diversified into the housing sector. In view of the high impact of the industry toward the environment, people tend to recognize these giant companies and ignore the existence of small and newly established companies. The existence of micro-and small housing development firms has been mostly ignored, particularly in large Malaysian cities, such as Kuala Lumpur, Penang, and Johor Bahru. Land cost is the main constraint for the start-up and survival of such firms. However, small and new firms can still take advantage of the less developed cities in Malaysia, where the land cost is still affordable. Many micro-and small housing developers operate in East Peninsular Malaysia, particularly in Kelantan and Terengganu, because of the lack of houses provided by large housing developers in this area.

As previously mentioned, private housing developers in Malaysia register with the Real Estate and Housing Developers' Association (REHDA). With branches in each state of Malaysia, REHDA serves a central function in ensuring that the views of housing developers are heard by relevant authorities and government agencies $[15,28]$. The REHDA Institute is responsible for providing courses and training to the industry players. The main task of REHDA Institute is to address and facilitate the training and education of the industry. Courses and seminars offered for industry players are related to legislation/regulations/policies/procedures, corporate/financial aspects, technical and infrastructure aspects, property market data, analytical tools, and marketing prospects. According to a survey by Ali [5], housing developers noted that the courses organized by the government sector, the private sector, or NGOs are more focused on the acts and licensing of the housing process than on the procedures or technical aspects.

Elias and Pihie [34] reveal that attending courses and seminars, especially after starting a company, promotes entrepreneurship and influences the success of an entrepreneur and a firm. Moreover, Ali [5] indicates that attending courses and seminars for business start-ups can ensure the smooth operation of a company. Attending short courses can be considered informal education, which has been recognized as an important tool for providing excellent exposure and information to an individual striving to become an expert, skilful, and welltrained entrepreneur. Examples of informal education (can be reaped by participants) on the part of housing developers are personal networking with other experienced entrepreneurs [35] and having a mentoring relationship with industry experts [36]. Exchanging ideas and opinions, participating in first-hand learning, and sharing experiences with fellow participants 
are all beneficial practices that housing entrepreneurs can utilize to achieve business longevity in the future [37].

\section{Training modules}

For this case, training provision recognizes the importance of entrepreneurial development in gaining insight into the business environment in which the business operates. The previous section provides profound justifications for the need to train new micro-and small housing entrepreneurs. In consideration of the high capital requirements for starting a business, the strategy of this course is to simultaneously equip micro-and small housing developers with managerial skills and technical knowledge. Given their lack of exposure to the housing business, people tend to associate the housing sector with high-risk production that requires high capital and involves long approval process. The aforementioned factors are among the main restrictions that hinder people from participating in this industry, thereby gradually creating a wide gap between large and small housing developers in Malaysia. Thus, the School of Housing, Building, and Planning of Universiti Sains Malaysia has formed a strategic partnership with an inspiring industry player, Maka Corporation Sdn Bhd, to offer courses on how to improve the potential of new housing developers in Malaysia. The decisive collaboration between the two parties has successfully produced basic and advanced modules for training new and existing housing developers. The main objective of this endeavour is to 'turn the potential entrepreneurs into knowledgeable housing developers' with marketing, management, and basic financial skills.

The first course was an introductory course on the housing development business and was conducted in June 2009. This course discusses the fundamental aspects of housing development to motivate nascent entrepreneurs to become fully-fledged housing developers. After a series of basic courses, due to high demand from the public, an advanced course was formulated to expose new developers and existing industry players to the current knowledge and industrial matters for project and business survivability. Introduced in August 2010, the advance course includes three aspects; inter alia entail industry updates, project management, and strategic management of the firm. The two-day course involves various speakers from government agencies, successful housing developers, and experienced consultants. The courses were held in select hotels in Kuala Lumpur because this capital city is a business hub for all Malaysians. The hotel arrangements and marketing of the courses were made by both parties, mainly through Internet marketing and brochure distribution. Among the courses offered, the least frequent is available once a year. The modules were reviewed and modified occasionally on the basis of the comments given by the participants to ensure the relevance of the content. The following section presents the latest module developed by the two organizations.

\subsection{Title of basic course: 'Kursus Asas Pemajuan Hartanah Perumahan'/Basic course on residential property development}

The objectives of the introductory course are as follows: 
a. To offer knowledge on housing development with regard to basic requirements for entrepreneurs to start a career as housing developers. Emphasis is placed on the requirements imposed by current housing laws and specific acts.

b. To expose prospective house builders to the related processes, procedures, and legislations of housing development-from acquiring or purchasing land to handing over the houses to homebuyers. Such exposure includes conversion and subdivision of land, obtaining approval for building plans, application for developer licenses and advertising permits, as well as obtaining 'Certificates of Occupancy' and other pertinent requirements and documents.

c. To present holistic guidance in planning and developing properties, such as training on how to conduct feasibility studies, plan cash flows, and prepare progress and project management reports.

d. To find proof for, or to verify, financing and insurance facilities available to house buyers and project developers.

e. To provide participants with opportunities to acquire first-hand experiences while receiving support and guidance from experienced developers on how to be successful.

The module includes the following:

1. Introduction to the Housing and Property Industry:

- Current scenario of the housing industry in Malaysia.

- Significance of the industry.

- Strength, weakness, opportunity, and threat (SWOT) analysis.

- Housing demand and market analysis.

2. Career as Housing Developers:

- Who is the developer? What does he/she do?

- Requirements of a housing developer.

- Career opportunities provided by the industry.

- Advantages of being a developer.

- Step-by-step strategy for becoming a developer.

3. Procedures for Land Acquisition:

- Type of land ownership.

- Guidelines for land acquisition.

- Identification of strategic land.

- Direct purchase vs. joint venture (JV). 
4. Terms and Conditions for Property Development Approval:

- Application for planning approval.

- Application for land conversion and subdivision.

- Building and infrastructure plan approval.

- Application for occupational certificate for handing over a property.

5. Procedures in Acquiring Developer's License and Advertisement Permit:

- Application for a developer's license.

- Application for a sale and advertisement permit.

- Facilities provided in portal MHLG.

6. Housing Sale and Marketing Strategy:

- Recognizing the housing market through statistical data.

- Marketing mix - the 4Ps principle (product, price, promotion, and place).

- Convincing people to purchase.

7. Common modes of marketing-advertisement, promotion, agent, etc.

8. Bank Financial Loan Facilities:

- Funding facilities provided by banks.

- Preparation of a working paper.

- Application and claim conditions and procedures.

- End financing for purchasers.

- Conditions of offer.

9. Treasury Housing Loan Facilities:

- Funding facilities provided by the Treasury Department, Ministry of Finance.

- Application and claim conditions and procedures.

- Conditions of offer.

- Common mistakes made by applicants.

10. Cash Flow Analysis:

- Factors that affect project viability.

- Feasibility analysis.

- Cash inflow and cash outflow. 
11. Project Implementation and Control:

- Procedures and types of contract.

- Progress and performance report.

- Monitoring your project.

12. Strategy for Initiating Business in Housing Industry:

- Starting a housing business.

- Dos and don'ts.

- Project development from the contractor and developer perspective.

\subsection{Title of advanced course: 'Kursus Lanjutan Pemajuan Hartanah Perumahan'/Advance course on residential property development}

The objectives of the advanced course are as follows:

a. To expose the participants to current updates and future prospects of the Malaysian housing industry.

b. To impart up-to-date information on government policies and procedures.

c. To guide the entrepreneurs toward business enhancement, especially in terms of project and financial management.

d. To provide knowledge on the latest tax principles affecting developers.

e. To share novel project designs and innovations for the participants to implement.

f. To identify strategic issues of the development process to ensure firm capability.

The module includes the following:

1. Property Market Survey: Present and Future:

- Current market and related data on the real estate sector.

- Demand and supply in every Malaysian state.

- Prospects of the industry.

2. Implementation of Industrialized Building System (IBS) in the Real Estate Industry:

- Introduction and concept of IBS.

- IBS applications, procedures, and rules.

- Advantages of IBS implementation.

- IBS manufacturers in Malaysia. 
3. Strata Titles Act 1985:

- Introduction to Strata Titles (Amendment) Act of 2007.

- Types of available schemes and strata title application.

- Application and processing procedure.

4. Innovations in the Development of Housing Projects:

- Sustainable project planning and integration.

- Development concept based on green technology.

- Recent innovations in project and housing design.

5. Effective Financial Management for Developers:

- Introduction to financial management for housing developers.

- Managing a project and company cash flow.

- Project feasibility analysis: cost, income, profit and loss, internal rate of return, etc.

- Overcoming cash flow deficits.

6. Taxation Matters Affecting Developers and the Housing Industry:

- Amendments to the Property Gains Tax Act of 1976.

- Tax management system for housing developers.

- Tax planning strategy for housing developers.

7. E-Marketing for Developers:

- Importance of new media.

- Types of online advertisement.

- Guideline for effective Internet marketing.

- Facebook adverts: data comprehension and profit calculation.

8. Key Performance Indicators (KPI) for Housing Firms:

- Definition of KPI.

- Job scope and performance target of a company.

- Scorecard preparation.

- KPI management as a performance benchmark.

9. Goods and Services Tax (GST): Implementation and Impacts:

- Introduction to GST.

- Scope and mechanism of GST. 
- Key terms of GST.

- Accounting effects and issues.

10. Branding for Housing Firms and Products:

- Strength of branding for image consolidation.

- Branding strategy and its effects.

- Relationship between branding and reputation.

- Paradigm shift for rebranding of housing developers.

\section{Assessment of the effectiveness of the courses}

For each course, the participants will be given a feedback form on which they can indicate their satisfaction with the course. The survey form is divided into four sections: evaluation of programme objectives, content, presentation, and overall appraisal. Nonetheless, for reference, the introductory course entails 11 presentations, whereas the advanced course involves ten presentations over a two-day workshop. Throughout the course, a three-point Likert scale comprising (1) Poor, (2) Good, and (3) Excellent ratings is applied. The measurement of mean value is used in this study to gauge the operationalized constructs. The subsequent analysis reveals the responses obtained from the latest courses handled by both parties.

\subsection{Introductory course}

Date of the course: 18-19 December 2013

Number of participants: 101

Number of responses: 84

\begin{tabular}{ll}
\hline Constructs & Mean Value \\
\hline Programme Objectives & 2.40 \\
\hline (a) What is your overall view of the programme? & 2.33 \\
\hline (b) How do you rate the quality of the programme content? & 2.44 \\
\hline Programme Contents & 2.30 \\
\hline (a) Ease of understanding & 2.39 \\
\hline (b) Presentation effectiveness & \\
\hline (c) Fulfilling self-development & \\
\hline
\end{tabular}

Presentation Assessment

How do you assess the performance of each presentation? 


\begin{tabular}{ll}
\hline Constructs & Mean Value \\
\hline (a) Presenter Paper 1 & 2.30 \\
\hline (b) Presenter Paper 2 & 2.45 \\
\hline (c) Presenter Paper 3 & 2.27 \\
\hline (d) Presenter Paper 4 & 2.40 \\
\hline (e) Presenter Paper 5 & 2.70 \\
\hline (f) Presenter Paper 6 & 2.31 \\
\hline (g) Presenter Paper 7 & 2.58 \\
\hline (h) Presenter Paper 8 & 2.31 \\
\hline (i) Presenter Paper 9 & 2.29 \\
\hline (j) Presenter Paper 10 & 2.52 \\
\hline (k) Presenter Paper 11 & 2.32 \\
\hline
\end{tabular}

Table 3. Mean values for analysis of introductory course

\subsection{Advanced course}

Date of latest course: 18-19 June 2014

Number of participants: 105

Number of responses: 81

Comparatively, both courses performed satisfactorily, because all recorded mean values were above 2.10 . Thus, at least $70 \%$ of the participants are satisfied with the services provided. Only a few dimensions require improvement, especially in terms of speaker presentation skills. Two presenters from the advanced course received a slightly lower score (mean=2.10, mean=2.19) compared with the other trainers. Thus, the organizer plans to replace the speakers with new appointed individuals who have more credibility. Good assessments from the participants are rather unexpected and can be attributed to with the module prepared by the organizers. Notably, the developed modules are highly related to the indispensable aspects of housing development, such as location, marketing, financial management, and product enhancement. Interestingly, Jaafar et al. [11] reported similar dimensions of findings for Malaysian homebuilders in terms of considering the preceding elements to succeed in this area. Given these facts, Banomyong and Supatne [38] emphasize the magnitude of networking (shall be elicited from short courses/trainings), and highlight that residential developers should jointly possess know-how and know-who to remain competitive.

Short courses are undoubtedly suitable for businesses because entrepreneurs have difficulty in fully committing their time for a long period of study [39]. Indeed, the courses elicited positive comments from participants. Based on the open-ended question enclosed in the feedback form, a number of positive suggestions were made such as, '...very good in terms of 


\begin{tabular}{ll}
\hline Constructs & Mean Value \\
\hline Programme Objectives & 2.54 \\
\hline (a) What is your overall view of the programme? & 2.48 \\
\hline (b) How do you rate the quality of the programme contents? & 2.51 \\
\hline Programme Contents & 2.35 \\
\hline (a) Ease of understanding & 2.38 \\
\hline (b) Presentation effectiveness & \\
\hline (c) Fulfilling self-development & \\
\hline
\end{tabular}

Presentation Assessment

How do you assess the performance of each presentation?

\begin{tabular}{lc}
\hline (a) Presenter Paper 1 & 2.42 \\
\hline (b) Presenter Paper 2 & 2.10 \\
\hline (c) Presenter Paper 3 & 2.27 \\
\hline (d) Presenter Paper 4 & 2.19 \\
\hline (e) Presenter Paper 5 & 2.49 \\
\hline (f) Presenter Paper 6 & 2.48 \\
\hline (g) Presenter Paper 7 & 2.44 \\
\hline (h) Presenter Paper 8 & 2.31 \\
\hline (i) Presenter Paper 9 & 2.80 \\
\hline (j) Presenter Paper 10 & 2.53 \\
\hline
\end{tabular}

Table 4. Mean value for analysis of advanced course

course module, though inadequate time provided,' '...the capability to insert a slot on innovation is laudable...' and 'an enjoyable course with relevant contents...' The positive responses were demarcated, and several participants from the introductory course look forward to attending the advanced course. Moreover, a few responses provided some suggestions for improvement, especially in terms of module development. A significant number of participants recommended a site visit/case study and experience-sharing session, as well as additional slots on marketing and finance to be included in the next courses. Notwithstanding the constructive remarks from participants, the courses need to undergo some modifications to further improve the content and methods of presentation. Pragmatically, both courses have successfully bridged the gap between theory and practice. 


\section{Conclusion and industry implication}

This book chapter provides different contributions to the research aspects, because these assessments are based on the training programme offered to industry players, and the contents are very much related to their business and project operation. The course on entrepreneurship training is the first course of its type to be offered in the housing development industry in Malaysia. With an interest in increasing the number of entrepreneur participants in the industry, the course must be of relevance to increase the knowledge of new entrants and existing industry players. Previously, training has been associated with specific traits known as 'competencies' [40], which consist of traits, skills, knowledge and attitudes [41). The improvement of these four characteristics will improve the individual performance of a job. These courses have covered all of the four competency aspects, and the survey indicates high satisfaction from the participants.

Although some scholars neglect the importance of human resource management, recent studies have proposed different views on training courses (c.f., 16,31-32,37,42-43), with the assumption that training will generate better products and an enhanced business environment. Training and career development are vital to any firm or organization that aims at progressing. Aside from employees having to attend training courses, owners/managers should also consider expanding the knowledge base through short-term courses. Owners/managers have insufficient time to attend training courses [40]. However, given proper time management and the worthwhile content of such courses, owners/managers are willing and eager to participate. Moreover, training programmes for nascent entrepreneurs can have important positive effects on economic development. In Malaysia, which has a housing development industry that is becoming conspicuously arduous, the presence of two-tier relative courses is welcome because the success of housing entrepreneurs can be nurtured without merely relying on personal attributes [7].

The initiative taken by the School of Housing, Building, and Planning of Universiti Sains Malaysia with strategic partners from the housing industry to set up modules on developing and empowering new housing developers in Malaysia shall be extolled and encouraged. Indeed, the dearth of entrepreneurship courses in the housing sector in Malaysia has resulted in a high demand for entrepreneurship education. The REHDA Institute only offers specific courses to existing players in the industry. Such a need is apparent in the number of attendees of both courses, with each course attracting more than 100 participants from various parts of Malaysia. The courses have not only attracted newcomers to the industry, but also existing players who are keen on gaining additional knowledge on project and business management. The housing industry has been acknowledged to have links to more than 100 upstream and downstream supply chains, and these training courses can serve as a good platform for them to meet and introduce themselves. Therefore, the programmes presented in this study can fill the research gap to nurture and nourish new industry players in the housing field. On a related note, the designed activities ensure the sustainability of entrepreneurial activities and supply alternative means for entrepreneurial cognition, intention, and readiness in a profound manner. 
The annual increases in the population and urbanization of Malaysia have resulted in factors that highlight the need for increased shelter-particularly in urban areas - thus increasing the demand on developers to provide additional houses and encouraging new players to enter the industry. With proper training and guidance, these new players will survive and will be able to compete with a larger group of industry actors. Housing developers should basically be furnished with knowledge and information regarding current market preferences. Mano et al. [37] believe that training courses provide a concrete stage for entrepreneurs to be proactive in obtaining customers. This step will inadvertently drive the sales margin toward a superior performance [43] because of changes in business practices [32]. An in-depth understanding of targeted consumer behaviour and attitude is critical for success, and for creating signature developments of outstanding quality and value. In addition, the existing Malaysian housing entrepreneurs need to have an acute understanding of entrepreneurial orientations in order to succeed in their ventures. Entrepreneurial orientations include confidence, courage, strong willpower, risk-taking, creativity, and innovativeness, all of which can be embedded within cognitive development through short courses, training and mentoring programmes, or even academic seminars and conferences leading to knowledge empowerment.

Henceforth, this trend should be emulated by other academic institutions around the globe in partnership with industry players. With this effort, the gap between theoretical value and pragmatic approach can be further minimized or even eliminated. Based on the perspectives of various parties involved in the programme (either participants or trainers), such courses are regarded as significant to the industry. Moreover, collaboration with local leaders with vast experience in this sector, as well as with the ministries, state government authorities, and other fellow players in the industry, is favourable for providing the required knowledge and information to prospective entrepreneurs. Meanwhile, a strong connection with successful mega players should be moulded for monitoring and mentoring purposes. From what has been accomplished, the mentoring programme has received positive feedback from industry players and has provided a new platform for educators, industry players, and relevant stakeholders to transfer their knowledge and share their valuable experiences with nascent developers. These challenging endeavours have given the university a good reputation and positive image. The training course is continuously being developed for future benefits to the industry.

From the researcher's viewpoint, the publications on industry training provided by the university and their industry partners are quite limited. This kind of strategic partnership will facilitate a win-win situation on both sides. Having a certificate from the university provides extra value to the courses, while private partners can support the module development. An overly academic approach would not be appropriate to practitioners. Changes in the modules according to new industry updates, rules, and regulations, would require input from private partners. Besides this, action research could be performed on these industry players to enhance the knowledge transfer between these two parties. 


\section{Author details}

Mastura Jaafar*, Syed Putra Syed Abu Bakar and Wan Mohd Dzulkifli Wan Daud

*Address all correspondence to: masturaj@usm.my

Department of Quantity Surveying, School of Housing, Building, and Planning, Universiti Sains Malaysia, Malaysia

\section{References}

[1] Tan TH. Sustainability and Housing Provision in Malaysia. Journal of Strategic Innovation and Sustainability 2011;7(1) 62-71.

[2] Case KE, Quigley JM, Shiller RJ. Comparing wealth effects: the stock market versus the housing market. Cambridge, MA: National Bureau of Economic Research; 2001. Working Paper No.: 8606.

[3] Grimes A, Kerr S, Aitken A. Housing and economic adjustment. Wellington: Motu Economic and Public Policy Research Trust; 2003. Motu Working Paper No.: 03-09.

[4] Yahya AZ. Government Housing Policies and Incentives: The Government Viewpoint. In: Mohd-Don A. (ed.) Housing a Nation: A Definitive Study. Kuala Lumpur: Cagamas Berhad; 1997. p189-207.

[5] Ali R. Entrepreneurship-related factors and firm performance: A study on the Bumiputera housing developers in Peninsular Malaysia. PhD thesis. Universiti Sains Malaysia; 2011.

[6] Maruani T, Amit-Cohen I. Characteristics of Developers and Their Relations to Open Space Conservation. Land Use Policy 2011;28(4) 887-897.

[7] Jaafar M, Nuruddin AR, Syed-Abu-Bakar SP. Business Success and Psychological Traits of Housing Developers. Australasian Journal of Construction Economics and Building 2014;14(2) 57-72.

[8] Buzzelli M, Harris R. Cities as the Industrial Districts of Housebuilding. International Journal of Urban and Regional Research 2006;30(4) 894-917.

[9] Wan-Mohd-Dzulkifli MA. Panduan dan Prosedur Asas Cadangan Pembangunan Projek Perumahan. Penang: Penerbit USM; 2009.

[10] Abdul-Aziz AR, Ho SY, Jaafar M. Impact of Firm Characteristics on the Value of Resources for Malaysian Private Housing Developers. Journal of Financial Management of Property and Construction 2007;12(2) 95-105. 
[11] Jaafar M, Nuruddin AR, Syed-Abu-Bakar SP. Business Successes of Malaysian Housing Developers. In: Wang J. (ed.) Encyclopedia of Business Analytics and Optimization. Hershey, PA: IGI Global; 2014. p418-428.

[12] Anikeeff MA, Sriram V. Construction Management Strategy and Developer Performance. Engineering, Construction and Architectural Management 2008;15(6) 504-513.

[13] Goh BL. Housing Today. In: Mohd-Don A. (ed.) Housing the Nation: A Definitive Study. Kuala Lumpur: Cagamas Berhad; 1997. p71-106.

[14] Othman A. The effect of the planning system on housing development: A study of developers' behaviour in Kuala Lumpur and Johor Bahru, Malaysia. PhD thesis. University of Aberdeen; 1999.

[15] Khalid MS. Abandoned housing development: The Malaysian experience. PhD thesis. Heriot-Watt University; 2010.

[16] Jaafar M, Wan-Daud WD. Strategic Collaborative Approach: A Case Study on Training New Housing Entrepreneurs in Malaysia. International e-Journal of Community \& Industry Engagement 2014;1(1) 10-19.

[17] Sirat M, Che-Hamat AF, Abdul-Aziz AR, Rahim A, Salleh H, Yaakob U. Low-Cost Housing in Urban Centres of Malaysia: Issues and Challenges. Penang: Penerbit USM; 1999.

[18] Agus MR. The Role of State and Market in the Malaysian Housing Sector. Journal of Housing and the Built Environment 2002;17 49-67.

[19] Bujang AA, Zarin HA, Jumadi N. The Relationship between Demographic Factors and Housing Affordability. Malaysian Journal of Real Estate 2010;5(1) 49-58.

[20] Khor SCS, Abu-Bakar AH. Incorporating Sustainable Management System into Housing Development Practice in Malaysia. International Journal of Sustainable Development 2012;15(3) 277-291.

[21] Idrus N, Ho CS. Affordable and quality housing through the low-cost housing provision in Malaysia. Paper presented at: Seminar of Sustainable Development and Governance; 2008 June 26; Toyohashi, Japan.

[22] Mahari Z. Demographic transition in Malaysia: The changing roles of women. Paper presented at the 15th Conference of Commonwealth Statisticians; 2011 February 7-10; New Delhi, India.

[23] Abu-Bakar AH, Razak AA, Abdullah S, Awang A, Perumal V. Critical Success Factors for Sustainable Housing: A Framework from the Project Management View. Asian Journal of Management Research 2010;1(1) 66-80.

[24] Abdul-Aziz AR, Jahn-Kassim PS. Objectives, Success and Failure Factors of Housing Public Private Partnerships in Malaysia. Habitat International 2011;35(1) 150-157. 
[25] Omar D. Communal Living Environment in Low Cost Housing Development in Malaysia. Asian Social Science 2008;4(10) 98-105.

[26] Abdullah AA, Harun Z, Abdul-Rahman H. Planning Process of Development Project in the Malaysian Context: A Crucial Brief Overview. International Journal of Applied Science and Technology 2011;1(2) 74-81.

[27] Sudin, PW. International Experiences III: Low-Cost Housing. In: Mohd-Don A. (ed.) Housing the Nation: A Definitive Study. Kuala Lumpur: Cagamas Berhad; 1997. p823-843.

[28] Jaafar M, Abdul-Aziz AR, Ali R. Entrepreneurship: A Critical Outlook on Housing Developers in Malaysia. The International Journal of Construction Management 2010;10(4) 77-101.

[29] Hynes B, Richardson I. Entrepreneurship Education: A Mechanism for Engaging and Exchanging with the Small Business Sector. Education+Training 2007;49(8/9) 732-744.

[30] Upton N, Sexton D, Moore C. Have we made a difference? An examination of career activity of entrepreneurship major since 1981. In: Hay M, Birley S, Bygrave WD, Churchill NC. (eds.) frontiers of entrepreneurship research, 1995: proceedings of the 15th Annual Entrepreneurship Research Conference. Wellesley, MA: Babson College; 1995.

[31] Farashah AD. The Process of Impact of Entrepreneurship Education and Training on Entrepreneurship Perception and Intention: Study of Educational System of Iran. Education+Training 2013;55(8/9) 868-885.

[32] de Mel S, McKenzie D, Woodruff C. Business Training and Female Enterprise StartUp, Growth, and Dynamics: Experimental Evidence from Sri Lanka. Journal of Development Economics 2014;106 199-210.

[33] Giné X, Mansuri G. Money or Ideas? A Field Experiment on Constraints to Entrepreneurship in Rural Pakistan. Washington, DC: World Bank; 2011.

[34] Elias H, Pihie ZAL. Profile of Malaysian Entrepreneurs in Relation to their Achievement Motivation. Malaysian Management Review 1995;30(4) 25-31.

[35] Baron RA, Ensley MD. Opportunity Recognition as the Detection of Meaningful Patterns: Evidence from Comparisons of Novice and Experienced Entrepreneurs. Management Science 2006;52(9) 1331-1344.

[36] Smith E, Perks S. Training Interventions Needed for Developing Black Micro-Entrepreneurial Skills in the Informal Sector: A Qualitative Perspective. SA Journal of Human Resource Management 2006;4(1) 17-26.

[37] Mano Y, Iddrisu AH, Yoshino Y, Sonobe T. How Can Micro and Small Enterprises in Sub-Saharan Africa Become More Productive? The Impacts of Experimental Basic Managerial Training. World Development 2012;40(3) 458-468. 
[38] Banomyong R, Supatn N. Thailand: Relationship Marketing in Thailand: A Case of the Real Estate Industry. In: Paliwoda S, Andrews T, Chen J. (eds.) Marketing Management in Asia. New York, NY: Routledge; 2013. p120-137.

[39] Raffo C, O'Connor J, Lovatt A, Banks M. Attitudes to Formal Business Training and Learning amongst Entrepreneurs in the Cultural Industries: Situated Business Learning through 'Doing with Others'. Journal of Education and Work 2000;13(2) 215-230.

[40] Sanchez, J.C. University Training for entrepreneurial competencies: Its impact in intention of venture creation. International. Journal Management Journal 2011;(7) 239-254).

[41] Stuart, R and Lindsay, P. Beyond the frame of management competencies: toward a contextually embedded framework of managerial competence in organization. Journal of European Industrial Training 1997;21(1) 26-33.

[42] Sharma H. Importance and Performance of Managerial Training in Indian Companies-An Empirical Study. Journal of Management Development 2014;33(2) 75-89.

[43] Valdivia M. Training or Technical Assistance for Female Entrepreneurship? Evidence from a Field Experiment in Peru. Washington, DC: World Bank; 2011. 